\title{
Publisher's Note: Transverse emittance preservation during bunch compression in the Fermi free electron laser [Phys. Rev. ST Accel. Beams 15, 020701 (2012)]
}

S. Di Mitri, E. M. Allaria, P. Craievich, W. Fawley, L. Giannessi, A. Lutman, G. Penco, S. Spampinati, and M. Trovo (Received 15 February 2012; published 21 February 2012)

This paper was published online on 13 February 2012 with two images of Fig. 6 and a missing Fig. 5. The figures have been set properly as of 16 February 2012.

Published by the American Physical Society under the terms of the Creative Commons Attribution 3.0 License. Further distribution of this work must maintain attribution to the author(s) and the published article's title, journal citation, and DOI. 